\title{
Determinants of the willingness-to-pay for HIV/ AIDS prevention: the case of mother-to-child transmission in selected hospitals in Ghana
}

Emmanuel Ayifah

From $16^{\text {th }}$ International Symposium on HIV and Emerging Infectious Diseases

Marseille, France. 24-26 March 2010

\section{Background}

Mother-to-child transmission (MTCT) is the primary route of HIV infection in children under 15 years of age. In Ghana PMTCT programme was piloted in two hospitals in Atua government hospital and St Martin de Porres Hospital in 2002 and later expanded to other health centres. In Ghana Prevention of Mother to Child Transmission (PMTCT) services are free. It is however worth noting that, with the ever increasing public health expenditure in recent years, the government cannot foot the bill on PMTCT all alone. There is therefore the need for individual contributions to ensure sustainability of HIV/AIDS and other health care interventions, hence the study to determine how much individuals will be willing to pay to prevent MTCT of HIV/AIDS.

\section{Methods}

The study employs the contingent valuation method to investigate the willingness-to-pay for the PMTCT of HIV/AIDS, as well as the determinants of pregnant women's willingness-to-pay for PMTCT of HIV/AIDS in three antenatal care centres in Ghana (Atua Government Hospital, St. Martins Deporres Hospital-Agormanya and the Central Regional Hospital-Cape Coast) using logit and OLS regression.

\section{Results}

About 91 percent of the respondents were willing to pay some amount of money for PMTCT of AIDS. The average willingness-to-pay by all the respondents was $\$ 4$ (GHC4.20). Results from both the logit and the OLS regressions indicate that income is the most significant

Correspondence: eayifah@yahoo.com

University of Ghana, Accra, Ghana

B̈̈Med Central 2010 Ayifah; licensee BioMed Central Ltd factor that affects the willingness-to-pay for PMTCT of HIV/AIDS. Other factors such as HIV/AIDS status, distance to antenatal clinic, age and marital status were also shown to have effect on the WTP for HIV/AIDS, though the results were not robust.

\section{Discussion}

The study indicate that pregnant women place high value on the PMTCT of HIV/AIDS programme in Ghana, hence their willingness to pay some amount of money for PMTCT.

Published: 11 May 2010

doi:10.1186/1742-4690-7-S1-P137

Cite this article as: Ayifah: Determinants of the willingness-to-pay for HIV/AIDS prevention: the case of mother-to-child transmission in selected hospitals in Ghana. Retrovirology 2010 7(Suppl 1):P137.

Submit your next manuscript to BioMed Central and take full advantage of:

- Convenient online submission

- Thorough peer review

- No space constraints or color figure charges

- Immediate publication on acceptance

- Inclusion in PubMed, CAS, Scopus and Google Scholar

- Research which is freely available for redistribution

Submit your manuscript at www.biomedcentral.com/submit 